PEMANFAATAN MEDIA SOSIAL SEBAGAI SARANA KOMUNIKASI DALAM PENCEGAHAN MELUASNYA WABAH COVID - 19

\title{
DIKALANGAN PELAJAR
}

La Masi $^{1}$, Muhammad Sudia ${ }^{2}$ Salim $^{3}$ Rahmad Prajono ${ }^{4}$, Sitti Sarina ${ }^{5}$

1,2,3,4,5 Jurusan Pendidikan Matematika, Universitas Halu Oleo. J1. HEA Mokodompit, Kampus Hijau Tridharma Andounohu Kendari

lamasi166@yahoo.com¹,muhammad_matematika@yahoo.co.id ${ }^{2}$,salim@uho.ac.id ${ }^{3}$,prajonorahmad@gmail.com, sarinasitti@gmail.com

\begin{abstract}
Abstrak
Kegiatan pengabdian kepada masyarakat ini melibatkan sepuluh orang mahasiswa untuk memberikan edukasi kepada para pelajar dalam bentuk pemanfaatan media sosial sebagai sarana komunikasi dalam pencegahan meluasnya wabah Covid-19. Peserta KKN-Tematik akan merancang konten dalam bentuk infografis dan video untuk memberikan edukasi kepada pelajar melalui media sosial para pelajar. Waktu pelaksanaan kegiatan ini mulai tanggal 11 Juni 2020 sampai 11 Juli 2020. Lokasi pelaksanaan kegiatan pengabdian ini dilaksanakan sesuai dengan domisili wilayah peserta KKN-Tematik dengan objek sasaran kegiatan yaitu para pelajar jenjang SMP, SMA, SMK. Hasil kegiatan pengabdian ini menunjukkan bahwa program pengabdian terlaksana dengan baik sehingga pemanfaatan media sosial para pelajar memberikan pengaruh yang positif terhadap pencegahan meluasnya wabah Covid-19 di kalangan pelajar. Hal ini ditunjukkan dengan terdapat 40 poster dan 10 video edukasi yang dihasilkan oleh peserta KKN-Tematik, masing-masing peserta telah menjangkau akun media sosial para pelajar melewati 10 orang, dan siswa memiliki respon positif terhadap pelaksaaan kegiatan KKN-Tematik ini.
\end{abstract}

Kata Kunci : Covid-19, media sosial, pelajar 


\section{PENDAHULUAN}

Masyarakat di negara penjuru dunia masih berjuang dalam menghadapi penyebaran pandemi Covid-19, termasuk Indonesia sendiri. Data kasus Covid-19 di Indonesia per tanggal 10 Juni 2020 menunjukkan kasus positif sebanyak 34.316 kasus, meninggal sebanyak 1.959 orang, sembuh sebanyak 12.129 orang (Batubara, 2020). Walaupun angka sembuh lebih tinggi dari angka yang meninggal, namun trafik data angka kasus positif terus meningkat setiap harinya sampai sekarang.

Peneliti di seluruh dunia terus melakukan berbagai usaha melalui serangkaian uji-uji tes vaksin untuk menghentikan penyebaran virus Covid-19. Namun, belum ada titik terang terkait produksi vaksin untuk membunuh virus Covid-19. Untuk bertahan dan terhindar dari virus Covid-19, yang harus dilakukan saat ini yaitumenerapkan tindakan pencegahan dengan semaksimal mungkin dari penyebaran virus covid-19. Begitu juga, kebijakan-kebijakan telah dikeluarkan oleh pemerintah Indonesia untuk mengurangi tingkat penyebaran virus Covid-19 mulai dengan memberlakukan social distancing, physical distancing hingga PSBB (pembatasan sosial berskala besar) untuk beberapa daerah di wilayah Indonesia.

Masyarakat juga tidak hanya menghadapi pandemi Covid-19 namun sering memperoleh informasi dalam bentuk hoax sehingga terjerumus ke dalam miskonsepsi mengenai virus Covid-19. Menurut (Wibowo, 2020) bahwa informasi hoax akan menambah beban pikiran masyarakat di tengah pandemi, belum lagi risiko kesehatan dan dampak wabah penyakit ini terhadap kehidupan sosial ekonomi sudah cukup berat. Oleh karena itu, peran masyarakat secara aktif untuk menyaring sumber berita yang kredibel dan bertanggung jawab.

Pandemi Covid-19 juga memberikan efek pada berbagai sektor kehidupan dan salah satu sektor pendidikan. Hasil keputusan Menteri Pendidikan dan Kebudayaan Republik Indonesia melalui surat edarannya Nomor 3 Tahun 2020 tentang pencegahan corona virus disease (Covid-19) Pada Satuan Pendidikan bahwa seluruh kegiatan pembelajaran baik di sekolah maupun perguruan tinggi dilaksanakan di rumah masing-masing melalui aplikasi yang tersedia (Kemdikbud, 2020). Kasus Covid-19 juga sudah mulai menyebar dan terdapat kasus positif di 34 provinsi se-Indonesia. Untuk provinsi Sulawesi Tenggara, data Covid-19 tertangal 10 Juni 2020 dengan rincian sebagai berikut: kasus positif 266 orang, meninggal 5 orang, sembuh 174 orang (Sultra, 2020). Dari 17 Kabupaten/Kota yang berada di provinsi Sulawesi Tenggara, semua sudah terkonfirmasi positif Covid-19.

Selama pandemi Covid-19 yang terjadi di Sulawesi Tenggara, kebijakan stakeholder setempat terhadap pelaksanaan pendidikan khususnya para pelajar yaitu belajar di rumah secara mandiri dan daring. Hal ini juga berdasarkan edaran Kepala Dinas Pendidikan Provinsi Sulawesi Tenggara nomor 423.7/1950/ DPK tertanggal 24 Maret 2020, salah satu fokus belajar siswa di rumah adalah pendidikan kecakapan hidup mengenai pandemi Covid-19 
(Dinas Pendidikan dan Kebudayaan Sultra, 2020).

Uraian kondisi kasus positif Covid-19 dan kebijakan pendidikan di wilayah Sulawesi Tenggara, maka diperlukan upaya secara maksimal untuk melakukan pencegahan penyebarluasan wabah Covid 19 pada kalangan pelajar sebagai aset bangsa yang harus dilindungi. Oleh karena itu, perlu upaya bersama untuk memutuskan rantai penyebaran virus Covid-19 yaitu melalui kegiatan pengabdian masyarakat terintegrasi KKN-tematik dengan memanfaatkan sarana media sosial yang dimiliki oleh para kalangan pelajar.

Media sosial merupakan aplikasi berbasis internet yang digunakan untuk menjalin komunikasi dengan orang lain (Pratama \& Sari, 2020). Pelajar merupakan kalangan remaja yang cukup familiar terhadap penggunaan media sosial. Pelajar masa kini identik dengan smartphone di tangan hampir 24 jam. Media sosial yang paling sering digunakan seperti facebook,whatsapp, twitter, path, youtube, Instagram, line, dan bbm. Media sosial sangat banyak menawarkan kemudahan yang membuat remaja betah berlama-lama dalam menggunakannya (Pratiwi, 2017). Menurut (Juwita, Budimansyah, \& Nurbayani, 2015) memasuki era globalisasi remaja merupakan kalangan yang sering menggunakan media sosial sebagai sarana untuk mencari informasi, hiburan, maupun berkomunikasi dengan teman di situs jejaring sosial. Media sosial saat ini juga menjadi wadah untuk para remaja mengekspresikan seluruh perasaannya dengan berbagai momen yang dibagikannya melalui media sosial melalui unggahan dalam bentuk tulisan, foto bahkan video (Medcom, 2019). Para remaja dalam menggunakan media sosial belum sepenuhnya membedakan mana yang akan memberikan dampak positif dan negatif untuk mereka.

Kegiatan pengabdian kepada masyarakat ini dalam bentuk KKN-Tematik yang melibatkan sepuluh orang mahasiswa untuk memberikan edukasi kepada para pelajar dalam bentuk pemanfaatan media sosial sebagai sarana komunikasi dalam pencegahan meluasnya wabah Covid-19. Peserta mahasiswa KKNTematik akan merancang konten dalam bentuk infografis dan video untuk memberikan edukasi kepada pelajar melalui media sosial para pelajar. Lembaga yang menjadi mitra program KKN-Tematik ini adalah sekolahsekolah jenjang SMP, SMA/SMK yang dekat dengan domisili peserta mahasiswa $\mathrm{KKN}$ Tematik.

Target yang ingin dicapai dari pelaksanaan kegiatan pengabdian kepada masyarakat program KKN-TEMATIK yaitu: (a) para pelajar memiliki pengetahuan terkait virus Covid-19, (b) para pelajar dapat terhindar dari paparan virus Covid-19, (c) para pelajar turut serta mensosialisasikan upaya pencegahan Covid-19 pada lingkungan tempat tinggalnya. 


\section{TINJAUAN PUSTAKA}

\section{Virus Covid-19}

Penyakit Covid-19 adalah penyakit menular yang disebabkan oleh SARS-CoV-2, salah satu jenis corona virus. Penyakit ini mengakibatkan pandemi corona virus 20192020. Penderita Covid-19 dapat mengalami demam, batuk kering, dan kesulitan bernapas. Sakit tenggorokan, pilek, atau bersin-bersin lebih jarang ditemukan. Pada penderita yang paling rentan, penyakit ini dapat berujung pada pneumonia dan kegagalan multiorgan (Wikipedia, 2020).

Covid-19 (Corona virus) merupakan keluarga besar virus yang menyebabkan penyakit pada manusia dan hewan. Pada manusia biasanya menyebabkan penyakit infeksi saluran pernapasan, mulai flu biasa hingga penyakit yang serius seperti Middle East Respiratory Syndrome (MERS) dan Sindrom Pernafasan Akut Berat/ Severe Acute Respiratory Syndrome (SARS). Coronavirus jenis baru yang ditemukan pada manusia sejak kejadian luar biasa muncul di Wuhan Cina, pada Desember 2019, kemudian diberi nama Severe Acute Respiratory Syndrome Coronavirus 2 (SARS-COV2), dan menyebabkan penyakit Coronavirus Disease-2019 (COVID-19) (Kemkes, 2020).

Virus Covid-19 menyebar dengan cepat dari orang ke orang melalui tetesan bersin atau batuk yang keluar dari orang dengan infeksi Covid-19. Karena cepatnya penyebaran virus ini, Organisasi Kesehatan Dunia (WHO) menyarankan untuk melakukan lima 5 ini demi mencegah penyebaran virus corona
(Putsanra, 2020) yaitu: (a) secara teratur dan menyeluruh bersihkan tangan dengan sabun dan air atau cairan berbasis alkohol yang bertujuan untuk membunuh virus yang mungkin ada di tangan, (b) pertahankan jarak fisik atau physical distancing setidaknya 1 meter (3 kaki) dengan orang lain, (c) hindari menyentuh mata, hidung dan mulut, (d) menjaga kebersihan pernapasan, (e) tetap di rumah jika merasa tidak sehat.

\section{Media Sosial}

Media sosial adalah sebuah media online dengan penggunanya dengan mudah berpartisipasi, berbagi, dan membuat isi meliputi blog, sosial network atau jejaring sosial, wiki, forum dan dunia virtual (Putri, Nurwati \& Budiarti, 2016). Media sosial merupakan alat komunikasi yang dimanfaatkan oleh pengguna untuk proses aktivitas sosial (Mulawarman \& Nurfitri, 2017). Pengguna media sosial dapat menemukan banyak sekali pilihan informasi yang diperlukan dengan mengetikan kata kunci di form yang disediakan oleh platform media sosial tersebut (Doni \& Faqih, 2017).

Guzzetti dalam (Felita et al., 2016) mengungkapkan bahwa dengan adanya media sosial, remaja memiliki komunitas online untuk memberikan kesempatan baginya berinteraksi sosial dengan orang lain dan memperoleh umpan balik tentang dirinya dari komunitas tersebut. (Kaplan \& Haenlein, 2010) mengungkapkan hampir $67 \%$ pengguna internet melakukan akses tiap hari, dengan para remaja sebanyak $36 \%$ mengakses internet beberapa kali sehari dan $27 \%$ lainnya sehari satu kali.

Adanya media sosial yang hadir pada kalangan remaja, akan membuat ruang privat melebur 
dengan ruang umum sehingga akan terjadi pergeseran budaya pada kalangan remaja yang tidak segan-segan mempublish segala aktivitas pribadinya untuk disampaikan kepada temantemannya melalui akun media sosial dalam membentuk identitas dirinya (Ayun, 2015).

\section{METODE PENELITIAN}

Program pengabdian kepada masyarakat ini berupa KKN-Tematik melibakan 4 dosen pembimbing lapangan dan 10 orang mahasiswa. Waktu pelaksanaan kegiatan KKN-Tematik ini mulai tanggal 11 Juni 2020 sampai 11 Juli 2020. Lokasi pelaksanaan kegiatan pengabdian ini dilaksanakan sesuai dengan domisili wilayah mahasiswa KKN-Tematik. Objek sasaran dari kegiatan pengabdian ini yaitu para pelajar yang berada pada jenjang SMP, SMA, SMK yang tinggal bersama domisili peserta KKN-Tematik.

Kegiatan pengabdian kepada masyarakat berupa KKN-Tematik ini memiliki tahapan-tahapan pelaksanaan yang terdiri dari: persiapan, pelaksanaan dan evaluasi. Pada tahapan persiapan kegiatan yang dilakukan adalah pengumpulan informasi dasar yang diperlukan terkait fokus sasaran kegiatan dan penjaringan calon peserta KKN-Tematik secara online.

Pada tahap pelaksanaan kegiatan memuat beberapa tahap, meliputi: pembekalan peserta, dan implementasi program. Pembekalan peserta melalui online menggunakan aplikasi teleconferences menyangkut materi dan teknik pelaksanaan KKN-Tematik di masyarakat serta penyiapan perlengkapan pendukung selama berada di lokasi KKN-Tematik. Materi akan disampaikan oleh tim pengabdian kepada masyarakat terkait teknis pembuatan infografis dan video disertai teknik penyampaian ke pelajar agar program ini KKN Tematik berhasil. Pada tahap implementasi program dilakukan melalui kegiatan sosialisasi program melalui media sosial. Pelajar yang menjadi obyek kegiatan adalah mereka yang berada tepat domisili peserta KKN-Tematik. Disamping melalui sosialisasi juga dilakukan penyuluhan secara edukasi kepada pelajar berupa penyampaian konten materi edukasi melalui media sosialnya terhadap pencegahan meluasnya wabah Covid-19. Para pelajar juga diajak secara persuasif untuk melakukan pencegahan meluasnya wabah Covid-19 dimulai dari lingkungan keluarganya sampai pada masyarakat sekitarnya.

Pada tahap evaluasi dilakukan dengan cara merekapitulasi semua hasil program berlangsung selama KKN-Tematik kemudian menentukan apakah pelaksanaan programprogram tersebut sudah sesuai dengan target yang diharapkan atau tidak. Untuk target pelajar yang dapat dijangkau pada masingmasing akun media sosialnya untuk masingmasing peserta KKN-Tematik adalah minimal 10 orang untuk satu sekolah.

Metode yang digunakan selama kegiatan KKN-Tematik berupa pemanfaatan media sosial sebagai sarana komunikasi dalam pencegahan meluasnya wabah Covid-19 pada kalangan pelajar dilakukan dengan cara penyampaian edukasi melalui media sosial para pelajar yang disertai dengan diskusi antara pelajar dan mahasiswa KKN-Tematik. Alat ukur yang digunakan yaitu seberapa 
jauh konten edukasi tersampaikan kepada media sosial pelajar dan respon pelajar terkait eduksi pencegahan covid-19 melalui media sosialnya.

Keberlanjutan program KKN-Tematik ini yaitu setelah terealisasikannya program-program edukasi pencegahan Covid-19 diharapkan tingkat kesadaran pelajar terhadap bahaya Covid-19 semakin baik sehingga dampak terpaparnya Covid-19 pada pelajar dapat teratasi dan terhindar. Harapan berikutnya agar program ini menjadi program penting bagi pemerintah desa/kelurahan setempat untuk memutus rantai penyebaran Covid-19.

\section{HASIL DAN PEMBAHASAN}

Kegiatan KKN-tematik melibatkan sepuluh orang mahasiswa yang berasal dari Jurusan Pendidikan Matematika Fakultas Keguruan dan Ilmu Pendidikan Universitas Halu Oleo. Peserta KKN-Tematik semuanya berdomisili di wilayah Provinsi Sulawesi Tenggara dengan sebaran 2 orang dari Kabupaten Muna, 3 orang dari Kabupaten Bombana, 1 orang dari Kabupaten Kolaka, 1 orang Kabupaten Konawe, 1 orang Kabupaten Buton, dan 2 orang dari Kota Kendari.

Kegiatan KKN-Tematik ini dimulai dengan tahap pemilihan fokus sasaran kegiatan dan pemilihan peserta KKN-Tematik. Fokus sasaran kegiatan memperhatikan situasi dan kondisi yang sedang terjadi saat ini yaitu pandemi Covid-19 dan dampak penyebarannya kepada para pelajar yang merupakan aset bangsa. Untuk pemilihan peserta KKNTematik dilakukan pengumuman secara online dan mengisi form pendaftan secara online pula. Pemilihan peserta KKN-Tematik mempertimbangkan kemampuan IT yang dimilikinya, dan domisili peserta yang memiliki jaringan internet.

Pada tahap pelaksanaan kegiatan dimulai dengan pembekalan peserta yang dilakukan secara online melalui aplikasi video conference dengan menggunakan zoom cloud meeting. Materi pembekalan memuat teknis pembuatan infografis dan pembuatan video edukasi serta konten yang terdapat dalam infografis dan video tersebut. Peserta juga dibekali tentang teknik penyampaian infografis dan video edukasi kepada para pelajar agar dapat mereka jangkau dan mudah mereka pahami.

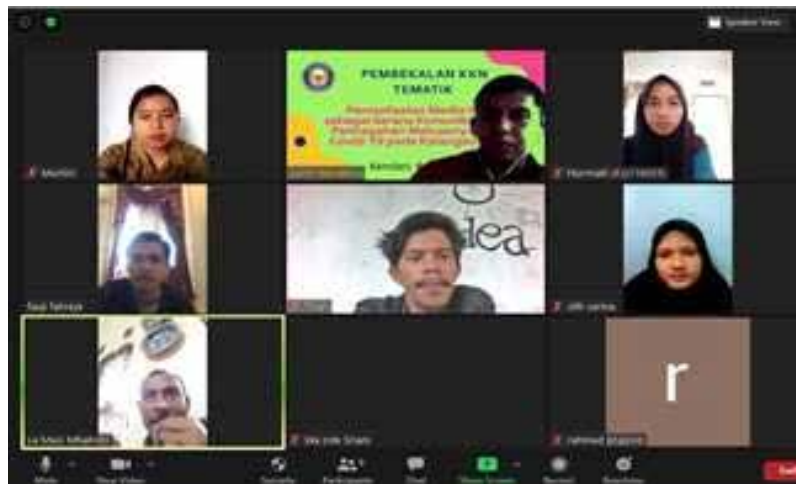

Gambar 1. Pembekalan Peserta Melalui Zoom Cloud Meeting

Pada tahap implementasi program, peserta KKN-Tematik terlebih dahulu mengidentifikasi pelajar yang memiliki media sosial beserta platform media sosial yang digunakan pelajar. Hasil indentifikasi menunjukkan platform yang digunakan pelajar adalah kebanyakan menggunakan facebook, disusul whatsapp, dan instagram. Selanjutnya, peserta KKNTematik melakukan proses pertemanan pada akun facebook pelajar, saling menfollow akun 
instagram, dan mendata nomor handphone pelajar untuk dimasukan dalam grup whatsapp. Setelah penataan pada akun media sosial pelajar, setiap peserta KKN-Tematik mendesain infografis sebanyak 4 dan video sebanyak 1 sehingga total infografis sebanyak 40 dan video edukasi sebanyak 10 .

Infografis dan video edukasi terkait pencegahan penyebarluasan Covid-19 yang telah dibuat oleh masing-masing peserta KKN-Tematik akan dibagikan kepada media sosial yang digunakan oleh para pelajar. Setiap minggu para pelajar akan mendapatkan infografis sebanyak satu buah yangakan dibagikan pada media sosialnya dan akan dilanjutkan proses sharing dan diskusi antara pelajar dan peserta KKN-Tematik terkait isi dari infografis tersebut. Selama 4 minggu para pelajar mendapatkan infografis tersebut dan satu buah video edukasi pada minggu kedua.
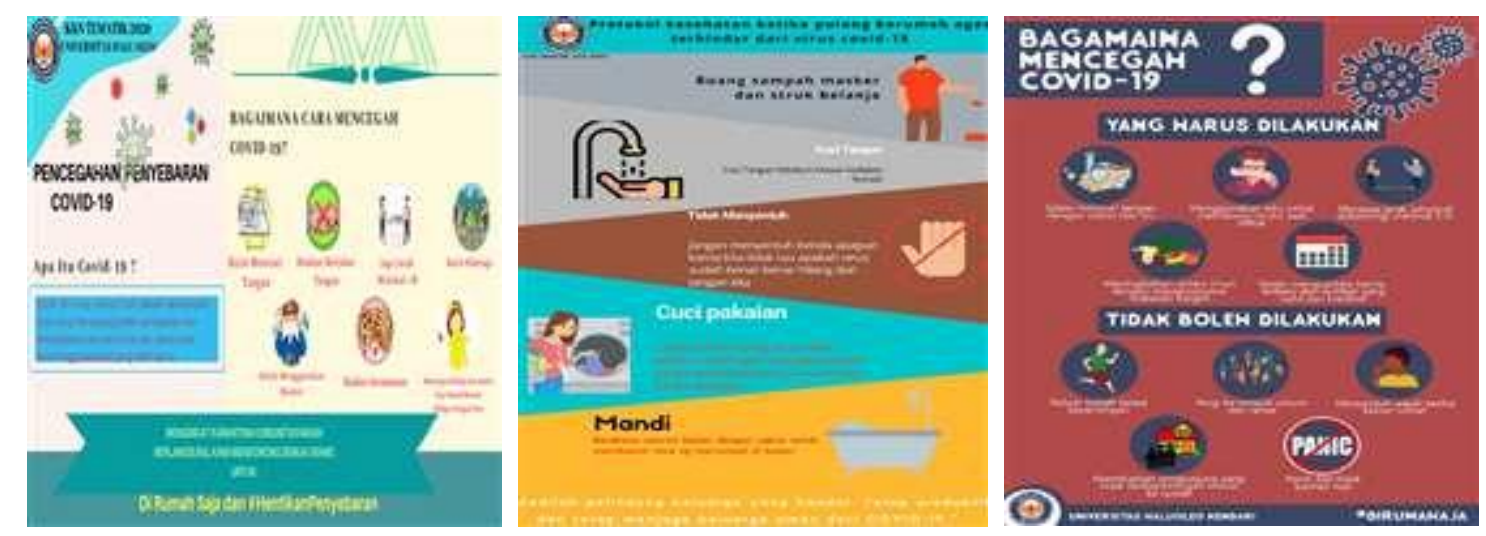

Gambar 2. Contoh Infografis terkait Edukasi Pencegahan Penyebaran Covid-19
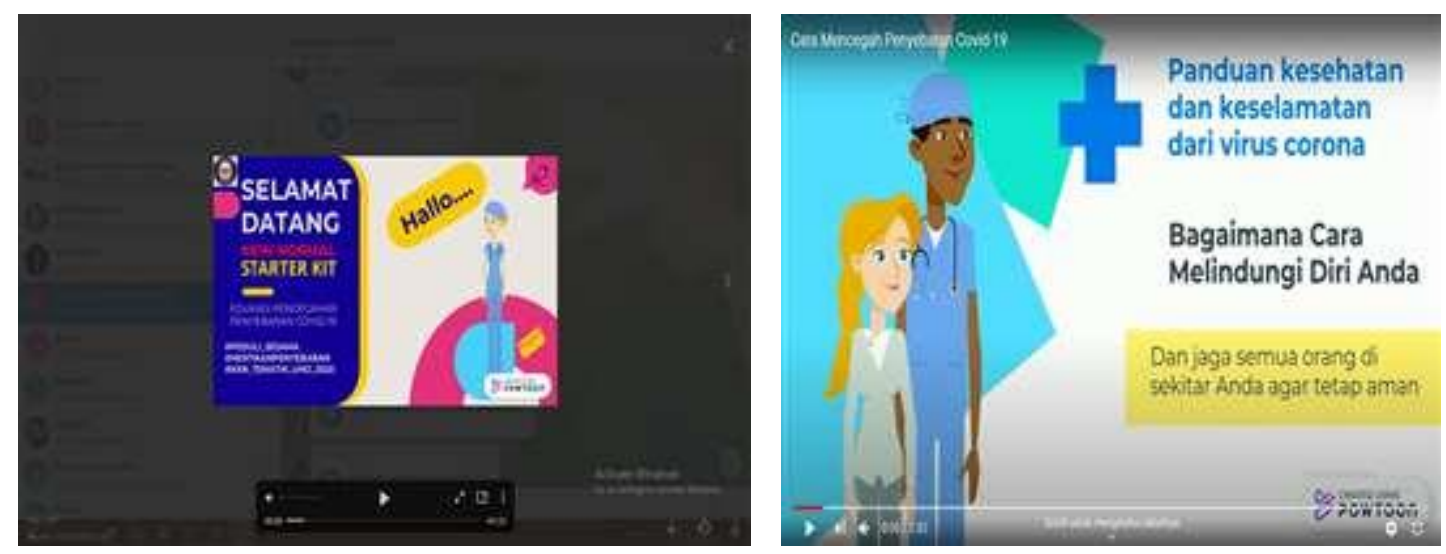

Gambar 2. Contoh Video Edukasi Pencegahan Penyebaran Covid-19 
HUMANISM Vol.1 No. 3 Desember 2020
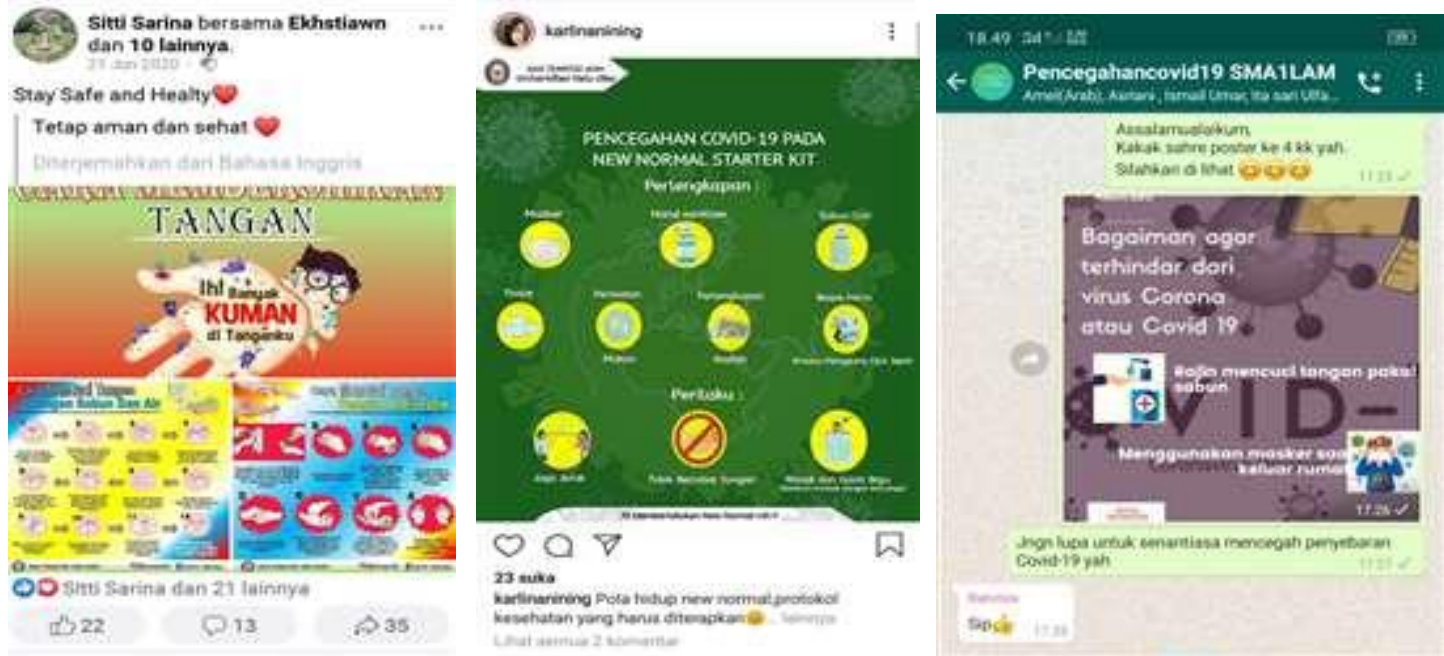

Gambar 3. Sharing Edukasi Pencegahan Covid-19 pada Media Sosial Pelajar

Hasil sharing konten edukasi infografis dan video yang dapat dijangkau kepada pelajar pada masing-masing sekolah tertera pada Tabel 1 berikut ini.

Tabel 1. Sharing Kontent Edukasi Infografis Dan Video Yang Dijangkau Pelajar

\begin{tabular}{cccc}
\hline $\begin{array}{c}\text { Peserta KKN- } \\
\text { Tematik }\end{array}$ & Nama Sekolah & Kabupaten/Kota & $\begin{array}{c}\text { Jumlah Pelajar Yang } \\
\text { Dijangkau Pada Media } \\
\text { Sosialnya }\end{array}$ \\
\hline R-01 & SMA Lambadia & Kolaka & 18 orang \\
R-02 & SMA Wawotobi & Konawe & 21 orang \\
R-03 & SMAN 3 Bombana & Bombana & 19 orang \\
R-04 & SMAN 3 Kendari & Kendari & 21 orang \\
R-05 & SMAN 4 Kendari & Kendari & 18 orang \\
R-06 & SMPN Satap 1 Tikep & Muna & 19 orang \\
R-07 & SMAN 1 Pasarwajo & Buton & 18 orang \\
R-08 & SMAN 9 Bombana & Bombana & 24 orang \\
R-09 & SMKN 7 Bombana & Bombana & 25 orang \\
R-010 & SMPN 1 Pasir Putih & Muna & 20 orang \\
& Total & & 203 orang \\
\hline
\end{tabular}

Target banyak pelajar yang dapat dijangkau pada akun media sosialnya adalah 10 orang untuk masing-masing sekolah. Namun, berdasarkan data yang ada pada Tabel 1 menunjukkan target tersebut telah dicapai dan melampui batas yang ditentukan untuk masing-masing peserta KKN-Tematik. Hasil ini menunjukkan bahwa penggunaan media sosial cukup efektif untuk memberikan edukasi kepada para pelajar terhadap pencegahan meluasnya wabah Covid-19 pada kalangan pelajar. Hal ini sesuai dengan pendapat (Irfan, 
Nursiah, \& Rahayu, 2019) bahwa penggunaan media sosial dapat memberikan efek yang baik terhadap motivasi yang ada pada diri siswa. Menurut (Salam, 2020) bahwa penggunaan media sosial whatsapp dapat terjalin komunikasi dan pertukaran informasi yang baik dengan sesamanya.

Kegiatan pencegahan meluasnya wabah Covid-19 melalui media sosial mendapat respon positif dari para pelajar. Salah satu pelajar mengatakan bahwa dengan adanya infografis dan video yang di share pada media sosial menjadi wadah untuk berbagi pengetahuan dan saling bertukar informasi terkait Covid-19 agar terhindar dari dampak virus Covid-19 ini. Pelajar lainnya juga memberikan respon bahwa pada situasi pandemic Covid-19 banyak pelajaran yang didapat dari edukasi konten infografis dan video yang disebarkan di media sosial kami sehingga dapat terhindar dari virus Covid-19. Hal ini juga sejalan dengan kegiatan yang dilakukan oleh (Zendrato, 2020) bahwa upaya pencegahan terhadap Covid-19 perlu ditingkatkan mengingat penyebaran virus Covid-19 sangat cepat dan menelan banyak korban.

\section{KESIMPULAN}

Kesimpulan dari kegiatan pengabdian kepada masyarakat ini bahwa program terlaksana dengan baik sehingga pemanfaatan media sosial para pelajar dapat dikatakan dapat memberikan pengaruh yang positif terhadap pencegahan meluasnya wabah Covid-19 di kalangan pelajar. Hal ini ditunjukkan dengan terdapat 40 poster dan 10 video edukasi yang dihasilkan oleh peserta KKN-Tematik, masing-masing peserta telah menjangkau akun media sosial para pelajar melewati 10 orang, dan siswa memiliki respon positif terhadap pelaksanaan kegiatan KKN-Tematik ini.

\section{UCAPAN TERIMAKASIH}

Ucapan terima kasih kepada Universitas Halu Oleo melalui Lembaga Penelitian dan Pengabdian Kepada Masyarakat (LPPM) yang telah membiayai pelaksanaan kegiatan pengabdian kepada masyarakat ini sehingga dapat berjalan sesuai dengan program yang telah ditetapkan.

\section{DAFTAR PUSTKA}

Ayun, P. Q. (2015). Fenomena Remaja Menggunakan Media Sosial dalam Membentuk Identitas. Channel: Jurnal Komunikasi, 3(2), 1-16. http://dx.doi. org/10.12928/channel.v3i2.3270

Batubara, P. (2020). Update Covid-19 di Indonesia 10 Juni 2020: Positif 34.316 Orang, 12.129 Sembuh \& 1.959 Meninggal. Retrieved June 28, 2020 from https://nasional.okezone.com/ read/2020/06/10/337/2227665/updatecovid-19-di-indonesia-10-juni-2020positif-34-316-orang-12-129-sembuh1-959-meninggal

Dinas Pendidikan dan Kebudayaan Sultra. (2020). Kebijakan Pendidikan Dalam Masa Darurat Penyebaran Covid - 19. Retrieved June 28, 2020 from https:// disdikbud.sultraprov.go.id/kebijakanpendidikan-dalam-masa-daruratpenyebaran-covid-19/ 
Doni, F. R., \& Faqih, H. (2017). Perilaku Penggunaan Media Sosial Pada Kalangan Remaja. IJSE-Indonesian Journal on Software Engineering, 3(2), 15-23. https://doi.org/10.31294/ijse. v3i2.2816

Felita, P., Siahaja, C., Wijaya, V., Melisa, G., Chandra, M., \& Dahesihsari, R. (2016). Pemakaian Media Sosial Dan Self Concept pada Remaja. Jurnal Ilmiah Psikologi MANASA, 5(1), 30-41.

Irfan, M., Nursiah, S., \& Rahayu, A. N. (2019). Pengaruh Penggunaan Media Sosial (Medsos) Secara Positif Terhadap Motivasi Belajar Siswa SD Negeri Perumnas Kecamatan Rappocini Kota Makassar. Jurnal Publikasi Pendidikan, 9(3), 262-272. https://doi. org/10.26858/publikan.v9i3.10851

Juwita, E.P., Budimansyah, D., \& Nurbayani, S. (2015). Peran Media Sosial Terhadap Gaya Hidup Siswa SMA Negeri 5 Bandung. Sosietas (Jurnal Pendidikan Sosiologi), 5(1). https:// doi.org/10.17509/sosietas.v5i1.1513

Kaplan, A. M., \& Haenlein, M. (2010). Users Of The World, Unite! The Challenges And Opportunities Of Social Media. Business Horizons, 53(1), 59-68.

Kemdikbud. (2020). Edaran Tentang Pencegahan Wabah COVID-19 di Lingkungan Satuan Pendidikan Seluruh Indonesia. Jakarta: Kementerian Pendidikan dan Kebudayaan Republik Indonesia.
Kemkes. (2020). Apakah Coronavirus dan Covid-19 itu?. Retrieved June 30, 2020 from https://covid19.kemkes.go.id/ qna-pertanyaan-dan-jawaban-terkaitcovid-19/\#Apakah_Coronavirus_dan_ COVID-19_itu

Medcom. (2019). Pentingnya Mengawasi Remaja dalam Menggunakan Media Sosial. Retrieved June 30, 2020 from https://mediaindonesia.com/read/ detail/267757-pentingnya-mengawasiremaja-dalam-menggunakan-mediasosial

Mulawarman, \& Nurfitri, A. D. (2017). Perilaku Pengguna Media Sosial beserta Implikasinya Ditinjau dari Perspektif Psikologi Sosial Terapan. Buletin Psikologi, 25(1), 36-44. https://doi. org/10.22146/buletinpsikologi.22759

Pratama, B. A., \& Sari, D.S. (2020). Dampak Sosial Intensitas Penggunaan Media Sosial Terhadap Kesehatan Mental Berupa Sikap Apatis di SMP Kabupaten Sukaharjo. Jurnal Gaster, 18(1), 6575. https://doi.org/10.30787/gaster. v18i1.487

Pratiwi, A. (2017). Pengaruh Media Sosial Bagi Remaja. Retrieved June 30, 2020 from https://www.kompasiana.com/ 